\title{
Evaluasi Pencapaian Kompetensi Perekam Medis Dan Informasi Kesehatan Di Rumah Sakit Kota Yogyakarta Berdasarkan Metode Self Assessment
}

\author{
Nuryati ${ }^{1}$, Nur Rokhman ${ }^{2}$, Linia Riski Andriyani ${ }^{3}$ \\ Program Studi D3 Rekam Medis dan Informasi Kesehatan/ Departemen Layanan dan Informasi \\ Kesehatan/ Sekolah Vokasi, Universitas Gadjah Mada, Indonesia ${ }^{1,2,3}$ \\ nur3yati@ugm.ac.id ${ }^{1}$, nurrokhman@ugm.ac.id², andriyanilinia@gmail.com ${ }^{3}$
}

\begin{abstract}
ABSTRAK
Latar Belakang: Perekam medis dalam memberikan pelayanan harus sesuai dengan kompetensi, berdasarkan pendidikan dan pelatihan serta berkewajiban memenuhi Standar Profesi Perekam Medis. Khususnya di rumah sakit wilayah Kota Yogyakarta belum pernah dilakukan penelitian mengenai tingkat pencapaian kompetensi perekam medis dan informasi kesehatan.

Tujuan: Memberikan gambaran mengenai pencapaian serta sumber kompetensi kerja perekam medis berdasarkan self assessment di rumah sakit wilayah Kota Yogyakarta.

Metode: Jenis penelitian adalah observasi deskriptif dengan pendekatan kuantitatif dan rancangan cross sectional. Sampel terdiri dari 101 Perekam Medis dan Informasi Kesehatan (PMIK) di RS Kota Yogyakarta. Teknik pengambilan data dengan studi dokumentasi dan kuisioner. Analisis data menggunakan analisis univariate.

Hasil: Tingkat pencapaian kompetensi PMIK di RS Kota Yogyakarta sebesar 75,11\%, pencapaian tertinggi pada kompetensi Profesionalisme yang luhur sebesar $81 \%$, sedangkan tingkat pencapaian kompetensi PMIK terendah di rumah sakit Kota Yogyakarta yaitu pada kompetensi Manajemen Organisasi dan Kepemimpinan sebesar $72 \%$. Berdasarkan masa dinas tingkat pencapaian tertinggi yaitu pada masa dinas 16-20 tahun sebesar $83 \%$ dan pencapaian terendah pada masa dinas $>20$ tahun yaitu sebesar $52 \%$. Sumber perolehan kompetensi PMIK di RS Kota Yogyakarta yaitu 36\% berasal dari kuliah, 9\% dari pelatihan dan $55 \%$ dari kerja. Sedangkan sesuai dengan masa dinas sumber perolehan kompetensi terbanyak pada kuliah yaitu $41 \%$ pada masa dinas 6-10 tahun, pelatihan 33\% pada masa dinas $>16$ tahun, dan kerja $86 \%$ pada masa dinas 11-15 tahun.
\end{abstract}

Kesimpulan: Tingkat pencapaian kompetensi PMIK di RS Kota Yogyakarta sebesar 75,11\% dengan sumber perolehan kompetensi sebanyak $55 \%$ berasal dari kerja.

Kata Kunci: kompetensi perekam medis; sumber perolehan kompetensi; self assessment

\begin{abstract}
Background: Medical record and health information when providing service should match with competency based on education and training and obliged to fulfill medical record standard. Especially in hospitals of Yogyakarta region no research has ever been conducted on the level of achievement and competency acquisition source of medical record and health information based on self-assessment in.

Objective: To describe the level of achievement and work competency acquisition source of medical record and health information based on self-assessment in hospitals of Yogyakarta region.

Methods: This research is observation descriptive with uses quantitative approach and cross-sectional framework. Samples were taken as many as 101 Perekam Medis dan Informasi Kesehatan (PMIK) in hospitals of Yogyakarta region. The data collection techniques are documentation study and questionnaire. The data analysis uses univariate analysis. Results: Level of achievement competency of the medical recorder and health information in hospitals in Yogyakarta region is 75,11\%. With the highest achievement $81 \%$ at first competency and lower achievement $72 \%$ at sixth competency. Based on years of service the highest achievement is $83 \%$ at $16-20$ years of service and the lowest is $52 \%$ at $>20$ years of service.
\end{abstract}

Conclusion: Level of achievement competency of medical record and health information in hospitals of Yogyakarta region is $75,11 \%$ with competency acquisition source of medical record and health information is $55 \%$ from work.

Keywords: medical record competency; competency acquisition source; self-assessment 


\section{PENDAHULUAN}

Sarana pelayanan kesehatan dalam pelayanan kepada pasien wajib menyelenggarakan rekam medis, oleh karena itu diperlukan tenaga perekam medis dan informasi kesehatan (PMIK). Berdasarkan Peraturan Menteri Kesehatan RI Nomor 55 Tahun 2013 tentang Penyelenggaraan Pekerjaan Perekam Medis, pada Pasal 1 ayat 1 dijelaskan bahwa perekam medis merupakan seorang yang telah lulus pendidikan Rekam Medis dan Informasi Kesehatan sesuai ketentuan perundang-undangan. Pasal 14 dijelaskan bahwa perekam medis dalam memberikan pelayanan harus sesuai dengan kompetensi, berdasarkan pendidikan dan pelatihan serta berkewajiban memenuhi Standar Profesi Perekam Medis.

Seiring dengan perkembangan jaman tuntutan kerja seorang pegawai rekam medis semakin berkembang hal ini mendorong organisasi profesi perekam medis Indonesia atau PORMIKI menyusun standar baru untuk kompetensi PMIK yang telah ditetapkan pada tanggal 15 November 2016. Sesuai dengan Surat Keputusan Dewan Pimpinan Pusat PORMIKI No. 08/PORMIKI/XI/2016 tentang Pemberlakuan Atas Draft Standar Kompetensi baru Perekam Medis dan Informasi Kesehatan, kompetensi dibagi atas:

1. Profesionalisme yang luhur;

2. Mawas diri dan pengembangan diri;

3. Komunikasi yang efektif;

4. Manajemen Data Kesehatan;

5. Pemanfaatan Ilmu Statistik Kesehatan untuk Riset Biomedis dan Manajemen Kualitas;

6. Manajemen Organisasi dan Kepemimpinan;

7. Pemanfaatan Teknologi Untuk Pengelolaan Rekam Medis dan Informasi Kesehatan;

Standar kompetensi baru tersebut dapat digunakan sebagai pedoman dalam kegiatan pendidikan maupun pekerjaan. Hal ini berarti semua kegiatan pembelajaran terkait rekam medis dan informasi kesehatan harus sudah berpedoman dengan standar kompetensi baru selain itu, semua tenaga PMIK yang bekerja di rumah sakit harus sudah mengikuti perkembangan jaman dan harus melakukan update ilmu guna menunjang pencapaian kompetensi yang maksimal. Untuk menambah pengetahuan serta update ilmu dapat diperoleh dari pelatihan ataupun perkembangan sistem kerja masing-masing instansi.

Sesuai dengan hasil wawancara dengan salah satu anggota PORMIKI dan PMIK di rumah sakit, diketahui bahwa tingkat pencapaian kompetensi kerja tenaga PMIK tidak terpantau sampai dengan saat ini karena perhitungan pencapaian kompetensi hanya sebatas dilakukan dengan mengikuti uji kompetensi PMIK yang dilakukan ketika seorang PMIK lulus dari perguruan tinggi. Sedangkan berdasarkan hasil wawancara dengan PMIK di Rumah Sakit Wilayah kota Yogyakarta, setelah bekerja umumnya petugas rekam medis hanya fokus dan kompeten pada bagian yang mereka kerjakan setiap hari dan tidak peduli dengan bagian lain yang bukan bagian dari pekerjaannya. Hal ini membuat seorang PMIK tidak berkembang. Selain itu, khususnya di Kota Yogyakata belum pernah dilakukan perhitungan pencapaian kompetensi tenaga PMIK di rumah sakit dengan metode self assessment atau penilaian diri sendiri, sehingga belum diketahui tingkat pencapaian kompetensi kerja tenaga PMIK di kota Yogyakarta.

Dalam Standar Akreditasi KARS 2012 bab 5 tentang kualifikasi dan pendidikan staf (KPS) staf profesional kesehatan, termasuk di dalamnya adalah PMIK, diharuskan menempuh pendidikan berkelanjutan untuk menjaga kredensial mereka dan bagaimana pendidikan staf ini dimonitor dan didokumentasikan. Kredensial sama halnya dengan pencapaian kompetensi dari tenaga kesehatan. Berdasarkan standar tersebut maka peneliti bermaksud untuk melakukan perhitungan pencapaian kompetensi pegawai perekam medis dan informasi kesehatan dengan metode self assesment di rumah sakit kota Yoyakarta. Hal ini bertujuan untuk memberikan gambaran ketercapaian kompetensi perekam medis dan informasi kesehatan, yang pada akhirnya dapat 
dijadikan gambaran dalam proses kredensial perekam medis dan informasi kesehatan.

Berdasarkan penelitian mengenai Pencapaian Kompetensi Perekam Medis dan Informasi Kesehatan: Studi Kasus di Daerah Istimewa Yogyakarta (Nuryati, 2016) didapatkan hasil bahwa pencapaian kompetensi $57 \%$ diperoleh saat bekerja. Penelitian ini bermaksud untuk melanjutkan penelitian (Nuryati, 2016), untuk mengetahui tingkat pencapaian dan sumber kompetensi perekam medis dan informasi kesehatan dengan metode self asessment, dimana penelitian dilaksanakan secara lebih spesifik yaitu dengan kuisioner yang berpatokan pada Surat Keputusan Dewan Pimpinan Pusat PORMIKI No. 08/PORMIKI/XI/2016 tentang Pemberlakuan Atas Draft Standar Kompetensi Baru Perekam Medis dan Informasi Kesehatan. Elemen kompetensi berdasarkan patokan tersebut isinya lebih menekankan kepada kompetensi kerja PMIK. Kuisioner yang telah dibuat dan disebarkan diisi oleh petugas rekam medis yang telah bekerja di Rumah Sakit Wilayah kota Yogyakarta minimal satu tahun.

Tenaga PMIK dalam memberikan pelayanan harus mengacu pada kompetensi, mengacu pada pendidikan dan pelatihan serta berkewajiban mematuhi Standar Profesi Perekam Medis. (Permenkes RI, 2013).

\section{Pendidikan}

Pendidikan yang ditempuh secara formal merupakan proses pengembangan kemampuan dan keterampilan sesuai dengan keinginan dari organisasi. Tujuan dari ditempuhnya pendidikan adalah menciptakan calon tenaga yang sesuai dengan keinginan organisasi. Penekanan dalam pendidikan adalah adanya pengembangan kemampuan umum yang meliputi area kemampuan kognitif, efektif, dan psikomotor.

2. Pelatihan

Pelatihan merupakan bagian dari metode penyeelenggaraan pendidikan, yang bertujuan untuk meningkatkan pengetahuan, sikap, dan keterampilan khusus dari individu atau sekelompok individu. Sedangkan dalam Priansa (2016) pelatihan merupakan upaya yang dirancang secara sistematis dengan tujuan mengembangkan aspek pengetahuan, keterampilan, dan sikap yang sesuai kebutuhan organisasi. Tujuan dan manfaat pelatihan diantaranya adalah produktivitas, kualitas, perencanaan dan analisis kebutuhan dari pegawai, etika dan moral, kompensasi secara tidak langsung, keselamatan dan kesehatan kerja, pencegahan kadaluarsa, dan pengembangan kemampuan pribadi.

3. Kerja

Dalam kamus besar bahasa indonesia dijelaskan arti kata kerja yaitu kegiatan melakukan sesuatu.

Fungsi dari self assessment adalah mengidentifikasi kekurangan dan kelebihan seseorang. Selain sebagai metode untuk mengidentifikasi kelemahan atau gap keterampilan dan kemampuan seseorang, self assessment juga menggambarkan beberapa fungsi potensi diri. Self assessment pada umumnya didefinisikan sebagai keterlibatan antara pelajar dalam berpendapat untuk mendefinisikan standar yang telah ditemui atau dipelajari (Eva \& Regehr, 2005). Model penilaian tersebut mengharapkan mahasiswa mampu menilai pekerjaan mereka sendiri, berdasarkan bukti dan indikator yang jelas, dengan tujuan memperbaiki kinerja di masa yang akan datang. (McMillan \& Hearn, 2008).

Berdasarkan penelitian dari Rolheiser \& Ross (2014) Self assessment merupakan salah satu metode untuk melihat ke dalam diri sendiri. Melalui assesment ini mahasiswa mampu mengidentifikasi kelebihan maupun kekurangannya, dari kekurangan tersebut dijadikan perbaikan (improvement goal).

\section{METODE}

Dalam penelitian ini jenis penelitian yang digunakan adalah observasi deskriptif dengan pendekatan kuantitatif. Penelitian deskriptif merupakan jenis penelitian untuk menggambarkan atau mendiskripsikan suatu keadaan di dalam suatu masyarakat atau exploratory study. Dalam penelitian ini akan menjawab pertanyaan bagaimana (how) dari suatu kondisi. Sangadji dan Sopiah (2010), menyatakan bahwa penelitian deskriptif merupakan jenis penelitian yang menekankan pada uraian terhadap fakta yang terjadi saat ini dari suatu populasi, pendapat, keadaan, 
maupun sikap dari individu terhadap organisasi dinilai. Sedangkan pendekatan kuantitatif dalam penelitian ini datanya digambarkan dan dianalisis menggunakan teknik statistik.

Jenis penelitian deskriptif kuantitatif yang dimaksud dalam penelitian ini adalah peneliti mendeskripsikan tingkat pencapaian dan sumber kompetensi tenaga PMIK berdasarkan self assessment di Rumah Sakit Wilayah Kota Yogyakarta berdasarkan perhitungan stastistik dari sumber data yang diperoleh.

Tabel 1. Jumlah Tenaga Perekam Medis dan Informasi Kesehatan di Rumah Sakit Kabupaten atau Kota Daerah Istimewa Yogyakarta tahun 2015

\begin{tabular}{clccc}
\hline No & \multicolumn{1}{c}{ Unit Kerja } & Jumlah Tenaga PMIK & Total \\
& & L & P & \\
\hline 1 & RS Bethesda & 5 & 8 & 13 \\
2 & RS Bethesda Lempuyangwangi & 0 & 5 & 5 \\
3 & RS DKT Dr Soetarto & 1 & 2 & 3 \\
4 & RS Happyland Medical Center & 1 & 7 & 8 \\
5 & RS Islam Hidayatullah & 0 & 3 & 3 \\
6 & RS Jogja & 8 & 18 & 26 \\
7 & RS Ludira Husada Tama & 0 & 2 & 2 \\
8 & RS Panti Rapih & 6 & 14 & 20 \\
10 & RS PKU Muhammadiyah & 5 & 6 & 11 \\
10 & RS KIA PKU Muhammadiyah & 1 & 2 & 3 \\
11 & RSK Anak 45 & 1 & 0 & 1 \\
\hline \multicolumn{2}{r}{ Jumlah } & 28 & 67 & 95 \\
\hline
\end{tabular}

Sumber : Buku Profil Kesehatan Tahun 2015 Kota Yogyakarta.

Sesuai dengan tabel 1 di atas, maka jumlah populasi dalam penelitian ini adalah 95 orang, akan tetapi setelah dilakukan studi pendahuluan terdapat tambahan sebanyak 5 pegawai rekam medis dan informasi kesehatan dari RS Mata Dr. Yap dan 1 pegawai rekam medis dan informasi kesehatan dari RS Bersalin Rachmi. Sehingga jumlah populasi menjadi 101 perekam medis dan informasi kesehatan.

Sampel adalah bagian yang mewakili seluruh populasi. Penentuan besar sampel dalam penelitian ini menggunakan rumus perhitungan dari Slovin, yaitu :

$$
\begin{aligned}
& \quad N \\
& \mathrm{n}=\frac{N 1+N(d) 2}{\text { keterangan }:} \\
& \mathrm{n}=\text { besar sampel; } \\
& \mathrm{N}=\text { besar populasi; } \\
& \mathrm{d}=\text { tingkat kepercayaan }(10 \%) ; \\
& \mathrm{n}=1011+101(0,1) 2=50 P M I K
\end{aligned}
$$

Sedangkan rancangan yang digunakan dalam penelitian ini adalah rancangan cross sectional atau potong lintang. Pengumpulan data pada penelitian ini untuk mengetahui tingkat pencapaian dan sumber kompetensi tenaga PMIK bersadarkan self assessment di Rumah Sakit Wilayah Kota Yogyakarta dilakukan pada satu waktu saja tanpa di amati perkembangan selanjutnya.

Populasi dalam penelitian ini adalah semua tenaga PMIK yang ada di Rumah Sakit Wilayah Kota Yogyakarta. Dengan distribusi jumlah pegawai sebagai berikut: 
populasi, tetapi hanya mendaftar banyaknya gugus yang ada di dalam populasi tersebut. Kemudian pengambilan sampel berdasarkan gugus-gugus tersebut.

Teknik pengambilan sampel cluster random sampling dalam penelitian ini adalah peneliti terlebih dahulu mengacak gugus atau cluster, yaitu rumah sakit di wilayah Kota Yogyakarta yang merupakan anggota populasi, kemudian dihitung anggota dari hasil acak gugus atau cluster tersebut sampai dengan hasil hitung anggota gugus atau cluster memenuhi jumlah sampel yang dibutuhkan. Sesuai teknik pengambilan sampel, terpilih empat rumah sakit yang dijadikan sebagai sampel yaitu RSUD Kota Yogyakarta, RS Mata Dr. Yap, RS KIA PKU Muhammadiyah Yogyakarta dan RS Bethesda Lempuyangwangi.

Instumen yang digunakan dalam penelitian ini adalah kuisioner yang elemen datanya berpatokan dengan SK DPP PORMIKI no 08/PORMIKI/XI/2016 tentang Pemberlakuan Atas Draft Standar Kompetensi Baru PMIK. Menurut Sangadji dan Sopiah (2010), Kuisioner merupakan kumpulan pertanyaan tertulis yang ditujukan kepada responden untuk memperoleh informasi.

Analisis data yang digunakan dalam penelitian ini adalah analisis univariate dengan menganalisis masing-masing variabel, yaitu tingkat pencapaian dan sumber kompetensi tenaga PMIK. Analisis yang digunakan berupa distribusi frekuensi dan presentase dari tiap variabel penelitian.

\section{HASIL DAN PEMBAHASAN}

1. Karakteristik Responden

Hasil penelitian yang ditunjukkan berdasarkan karakter dari responden. Karakter responden disusun berdasarkan umur responden, jenis kelamin responden, dan masa kerja responden.

a. Umur Responden

Berdasarkan data yang terkumpul, maka jumlah responden dengan umur antara 20-29 tahun sebesar 38 responden atau sebesar $75 \%$, responden dengan umur antara 30-39 tahun sebesar 11 responden atau sebesar 22\%, responden dengan umur antara $40-49$ tahun sebesar 1 responden atau sebesar $2 \%$, dan responden dengan umur antara 50-59 tahun sebesar 1 responden atau sebesar $2 \%$. Tabel data jumlah responden berdasarkan kategori umur ditunjukkan pada tabel di bawah ini:

Tabel 1 Karakteristik Responden Berdasarkan Umur

\begin{tabular}{cccc} 
No & Kategori Umur & Jumlah & Persentase \\
\hline 1 & $20-29$ & 36 & 71 \\
2 & $30-39$ & 12 & 24 \\
3 & $40-49$ & 2 & 4 \\
4 & $50-59$ & 1 & 2 \\
\hline & Total & 51 & 100 \\
\hline
\end{tabular}

b. Jenis Kelamin Responden

Berdasarkan data yang terkumpul, maka jumlah responden yang berjenis kelamin perempuan sebesar 34 responden atau sebesar $67 \%$ dan responden yang berjenis kelamin laki - laki sebesar 17 responden atau sebesar 33\%. Tabel data jumlah responden berdasarkan jenis kelamin ditunjukkan pada tabel di bawah ini:

Tabel 2. Karakteristik Responden Berdasarkan Jenis Kelamin

\begin{tabular}{cccc}
\hline No & Jenis Kelamin & Jumlah & Persentase \\
\hline 1 & Perempuan & 34 & 67 \\
2 & Laki - laki & 17 & 33 \\
\hline & Total & 51 & 100 \\
\hline
\end{tabular}

c. Masa Kerja Responden

Berdasarkan data yang terkumpul, maka jumlah responden dengan masa kerja $1-5$ tahun sebesar 32 responden atau sebesar 63\%, responden dengan masa kerja 6-10 tahun sebesar 15 responden atau sebesar 29\%, responden dengan masa kerja 11 - 15 tahun sebesar 2 responden atau sebesar $4 \%$, dan responden dengan masa kerja lebih dari 16 tahun sebesar 2 responden atau sebesar $4 \%$. Tabel data jumlah responden berdasarkan kategori masa dinas ditunjukkan tabel di bawah ini:

Tabel 3. Karakteristik Responden Berdasarkan Masa Kerja

\begin{tabular}{lccc}
\hline No & Kategori Masa Dinas & Jumlah & Persentase \\
\hline 1 & $1-5$ & 32 & 63 \\
2 & $6-10$ & 15 & 29 \\
3 & $11-15$ & 2 & 4 \\
4 & $>16$ & 2 & 4 \\
\hline Total & & 51 & 100 \\
\hline
\end{tabular}

d. Jenis Rumah Sakit Responden

Berdasarkan data yang terkumpul, maka jumlah responden yang bekerja di rumah 
sakit umum sebesar 37 responden atau sebesar $73 \%$ dan responden yang bekerja di rumah sakit khusus sebesar 14 responden atau sebesar 27\%. Tabel data jumlah responden berdasarkan katogori masa dinas ditunjukkan tabel di bawah ini:

Tabel 4. Karakteristik Responden Berdasarkan Jenis Rumah Sakit

\begin{tabular}{cccc}
\hline No & Jenis Rumah Sakit & Jumlah & Prosentase \\
\hline 1 & Umum & 37 & 73 \\
2 & Khusus & 14 & 27 \\
\hline & Total & 51 & 100 \\
\hline
\end{tabular}

e. Kurikulum yang Diterima Saat PMIK Menempuh Pendidikan Tinggi

Berdasarkan data yang terkumpul, maka jumlah responden yang menempuh pendidikan tinggi dengan kurikulum sebelum tahun 2012 adalah sebesar 25 responden atau sebesar $49 \%$, dan responden yang menempuh pendidikan tinggi dengan kurikulum setelah tahun 2012 adalah sebesar 26 responden atau sebesar 51\%. Tabel data jumlah responden berdasarkan kategori kurikulum yang diterima saat menempuh pendidikan tinggi ditunjukkan tabel di bawah ini:

Tabel 5 Karakteristik Responden Berdasarkan Kurikulum yang Diterima Saat PMIK Menempuh Pendidikan Tinggi

\begin{tabular}{llcc}
\hline No & Kurikulum 2012 & Jumlah & Persentase \\
\hline 1 & Sesudah & 25 & 49 \\
2 & Sebelum & 26 & 51 \\
\hline Total & & 51 & $\mathbf{1 0 0}$ \\
\hline
\end{tabular}

2. Sumber Pencapaian Kompetensi PMIK

a. Persentase dari sumber pencapaian kompetensi oleh PMIK di rumah sakit di Kota Yogyakarta

Berdasarkan hasil penelitian, persentase sumber pencapaian kompetensi adalah sebagai berikut:

Tabel 6 Persentase Sumber Pencapaian Kompetensi PMIK di Rumah Sakit di Kota Yogyakarta

\begin{tabular}{ccccc}
\hline & Kuliah & Pelatihan & Kerja & Total \\
\hline Jumlah & 2689 & 736 & 4078 & 7503 \\
Persentase & 36 & 10 & 54 & 100 \\
\hline
\end{tabular}

Berdasarkan tabel 6, diketahui bahwa persentase tertinggi dari sumber pencapaian kompetensi PMIK adalah dari kerja yaitu sebesar 54\% dengan jumlah data 4078 dari total data 7503 , selanjutnya dari kuliah yaitu sebesar 34\% dengan jumlah data 2689 dari total data 7503, dan dari pelatihan sebesar 10\% dengan jumlah data 736 dari total data 7503.

Berdasarkan tabel 6, diketahui bahwa gap yang terjadi antara sumber pencapaian kompetensi dari kerja dan kuliah adalah sebesar $18 \%$.

b. Persentase Sumber Pencapaian Kompetensi PMIK di Rumah Sakit di Kota Yogyakarta Berdasarkan Area Kompetensi

Berdasarkan hasil penelitian, persentase sumber pencapaian kompetensi pada masingmasing area kompetensi adalah sebagai berikut:

Tabel 7. Sumber Pencapaian Kompetensi PMIK di Rumah Sakit di Kota Yogyakarta Berdasarkan Area Kompetensi

\begin{tabular}{clllllllll}
\hline \multirow{2}{*}{ No } & \multirow{2}{*}{ Area } & Kuliah & $\begin{array}{l}\text { Jumlah } \\
\text { Latihan }\end{array}$ & Kerja & $\begin{array}{l}\text { Jumlah } \\
\text { Data }\end{array}$ & Kuliah & $\begin{array}{c}\text { Persentase } \\
\text { Latihan }\end{array}$ & Kerja & Gap \\
\hline 1 & 1 & 568 & 105 & 596 & 1269 & $45 \%$ & $8 \%$ & $47 \%$ & $2 \%$ \\
2 & 2 & 205 & 59 & 297 & 561 & $37 \%$ & $11 \%$ & $53 \%$ & $16 \%$ \\
3 & 3 & 184 & 69 & 371 & 624 & $29 \%$ & $11 \%$ & $59 \%$ & $30 \%$ \\
4 & 4 & 305 & 103 & 545 & 953 & $32 \%$ & $11 \%$ & $57 \%$ & $25 \%$ \\
5 & 5 & 212 & 58 & 295 & 565 & $38 \%$ & $10 \%$ & $52 \%$ & $15 \%$ \\
6 & 6 & 632 & 191 & 1186 & 2009 & $31 \%$ & $10 \%$ & $59 \%$ & $28 \%$ \\
7 & 7 & 583 & 151 & 788 & 1522 & $38 \%$ & $10 \%$ & $52 \%$ & $13 \%$ \\
\hline Nilai Max & $\mathbf{2 0 0 9}$ & $\mathbf{6 3 2}$ & $\mathbf{1 9 1}$ & $\mathbf{1 1 8 6}$ & $\mathbf{4 5 \%}$ & $\mathbf{1 1 \%}$ & $\mathbf{5 9 \%}$ & $\mathbf{3 0 \%}$ \\
\hline Nilai Min & $\mathbf{5 6 1}$ & $\mathbf{1 8 4}$ & $\mathbf{5 8}$ & $\mathbf{2 9 5}$ & $\mathbf{2 9 \%}$ & $\mathbf{8 \%}$ & $\mathbf{4 7 \%}$ & $\mathbf{2 \%}$ \\
\hline
\end{tabular}


Evaluasi Pencapaian Kompetensi Perekam Medis Dan Informasi ...

Perbandingan sumber pencapaian kompetensi PMIK di rumah sakit di Kota Yogyakarta pada setiap area kompetensi yang

dipilih oleh responden ditunjukkan pada gambar 1 di bawah ini.

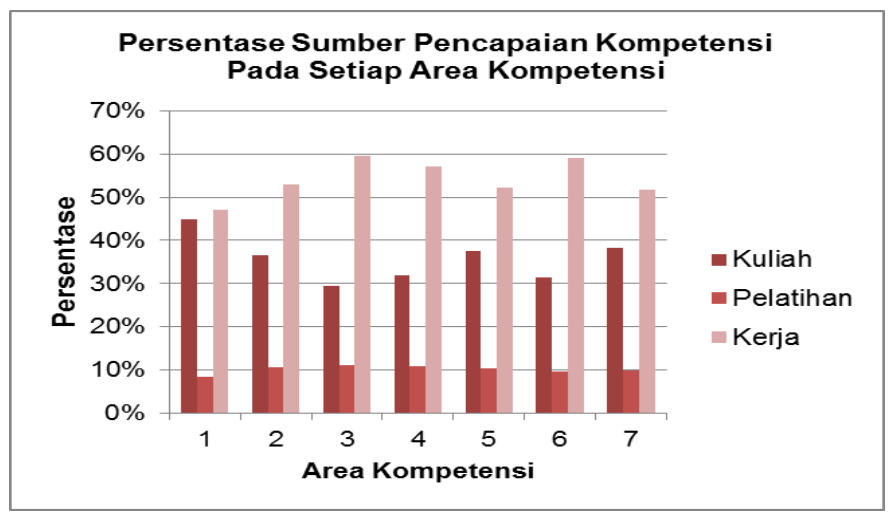

Gambar 1. Persentase Sumber Pencapaian Kompetensi PMIK Pada Setiap Area Kompetensi

c. Persentase Sumber Pencapaian bekerja di rumah sakit di Kota Yogyakarta Kompetensi PMIK di Rumah Sakit di berdasarkan masa kerja adalah sebagai Kota Yogyakarta Berdasarkan Masa Kerja Berdasarkan hasil penelitian, persentase sumber pencapaian kompetensi PMIK yang

Tabel 8. Sumber Pencapaian Kompetensi PMIK di Rumah Sakit di Kota Yogyakarta Berdasarkan Masa Kerja

\begin{tabular}{|c|c|c|c|c|c|c|c|c|c|}
\hline \multirow[b]{2}{*}{ No } & \multirow{2}{*}{$\begin{array}{c}\text { Masa } \\
\text { Kerja } \\
\text { (Tahun) }\end{array}$} & \multicolumn{3}{|c|}{ Jumlah } & \multirow{2}{*}{$\begin{array}{c}\text { Jumlah } \\
\text { Data }\end{array}$} & \multicolumn{3}{|c|}{ Persentase } & \multirow{2}{*}{ Gap } \\
\hline & & Kuliah & Latihan & Kerja & & Kuliah & Latihan & Kerja & \\
\hline 1 & $1-5$ & 1606 & 339 & 2465 & 4410 & $36 \%$ & $8 \%$ & $56 \%$ & $19 \%$ \\
\hline 2 & $6-10$ & 754 & 98 & 1118 & 1970 & $38 \%$ & $5 \%$ & $57 \%$ & $18 \%$ \\
\hline 3 & $11-15$ & 30 & 0 & 196 & 226 & $13 \%$ & $0 \%$ & $87 \%$ & $73 \%$ \\
\hline 4 & $>15$ & 299 & 299 & 299 & 897 & $33 \%$ & $33 \%$ & $33 \%$ & $0 \%$ \\
\hline \multicolumn{2}{|c|}{ Nilai Max } & 1606 & 339 & 2465 & 4410 & $38 \%$ & $33 \%$ & $87 \%$ & $73 \%$ \\
\hline \multicolumn{2}{|c|}{ Nilai Min } & 30 & 0 & 196 & 226 & $13 \%$ & $0 \%$ & $33 \%$ & $0 \%$ \\
\hline
\end{tabular}

Perbandingan sumber pencapaian yang dipilih oleh responden ditunjukkan kompetensi PMIK di rumah sakit di Kota pada gambar 2 di bawah ini. Yogyakarta berdasarkan masa kerja PMIK

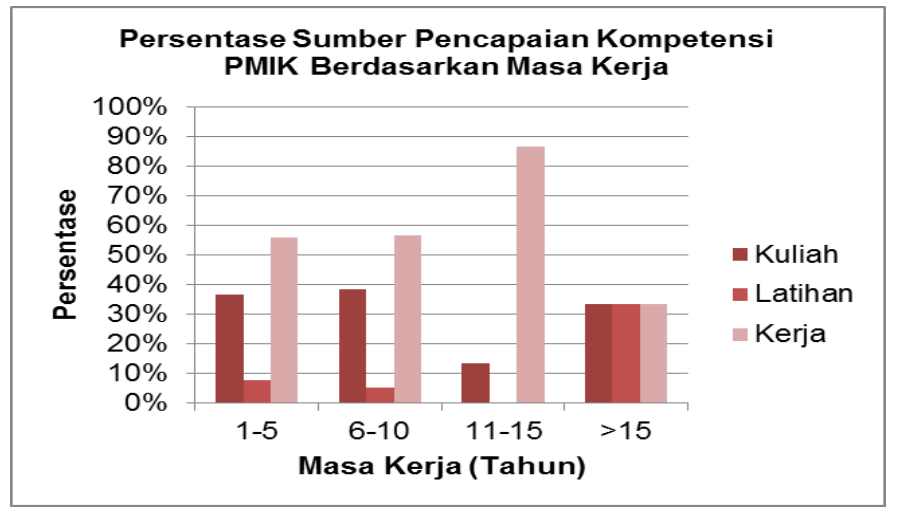

Gambar 2. Persentase Sumber Pencapaian Kompetensi PMIK Berdasarkan Masa Kerja 
Evaluasi Pencapaian Kompetensi Perekam Medis Dan Informasi ...

d. Persentase Sumber Pencapaian Kompetensi PMIK di Rumah Sakit di Kota Yogyakarta Berdasarkan Jenis Rumah Sakit
Berdasarkan hasil penelitian, persentase sumber pencapaian kompetensi PMIK yang bekerja di rumah sakit di Kota Yogyakarta berdasarkan jenis rumah sakit adalah sebagai berikut:

Tabel 9. Sumber Pencapaian Kompetensi PMIK di Rumah Sakit di Kota Yogyakarta Berdasarkan Jenis Rumah Sakit

\begin{tabular}{|c|c|c|c|c|c|c|c|c|c|}
\hline \multirow{2}{*}{ No } & \multirow{2}{*}{$\begin{array}{l}\text { Jenis } \\
\text { Rumah } \\
\text { Sakit }\end{array}$} & \multicolumn{3}{|l|}{ Jumlah } & \multirow{2}{*}{$\begin{array}{l}\text { Jumlah } \\
\text { Data }\end{array}$} & \multicolumn{3}{|c|}{ Persentase } & \multirow{2}{*}{ Gap } \\
\hline & & Kuliah & Latihan & Kerja & & Kuliah & Latihan & Kerja & \\
\hline 1 & Khusus & 784 & 22 & 756 & 1562 & $50 \%$ & $1 \%$ & $48 \%$ & $-2 \%$ \\
\hline 2 & Umum & 1905 & 714 & 3322 & 5941 & $32 \%$ & $12 \%$ & $56 \%$ & $24 \%$ \\
\hline \multicolumn{2}{|c|}{ Nilai Max } & 1905 & 714 & 3322 & 5941 & $50 \%$ & $12 \%$ & $56 \%$ & $24 \%$ \\
\hline \multicolumn{2}{|c|}{ Nilai Min } & 784 & 22 & 756 & 1562 & $32 \%$ & $1 \%$ & $48 \%$ & $-2 \%$ \\
\hline
\end{tabular}

e. Persentase Sumber Pencapaian Kompetensi PMIK di Rumah Sakit di Kota Yogyakarta Berdasarkan Kurikulum yang Diterima Saat PMIK Menempuh Pendidikan Tinggi
Berdasarkan hasil penelitian, persentase sumber pencapaian kompetensi PMIK yang bekerja di rumah sakit di Kota Yogyakarta berdasarkan kurikulum yang diterima saat pmik menempuh pendidikan tinggi adalah sebagai berikut:

Tabel 10 Sumber Pencapaian Kompetensi PMIK di Rumah Sakit di Kota Yogyakarta Berdasarkan Kurikulum yang Diterima Saat PMIK Menempuh Pendidikan Tinggi

\begin{tabular}{|c|c|c|c|c|c|c|c|c|c|}
\hline \multirow[t]{2}{*}{ No } & \multirow{2}{*}{$\begin{array}{l}\text { Kurikulum } \\
2012\end{array}$} & \multicolumn{3}{|c|}{ Jumlah } & \multirow{2}{*}{$\begin{array}{l}\text { Jumlah } \\
\text { Data }\end{array}$} & \multicolumn{3}{|c|}{ Persentase } & \multirow{2}{*}{ Gap } \\
\hline & & Kuliah & Latihan & Kerja & & Kuliah & Latihan & Kerja & \\
\hline 1 & Sebelum & 1245 & 413 & 2227 & 3885 & $32 \%$ & $11 \%$ & $57 \%$ & $25 \%$ \\
\hline 2 & Sesudah & 1444 & 323 & 1851 & 3618 & $40 \%$ & $9 \%$ & $51 \%$ & $11 \%$ \\
\hline \multicolumn{2}{|c|}{ Nilai Max } & 1444 & 413 & 2227 & 3885 & $40 \%$ & $11 \%$ & $57 \%$ & $25 \%$ \\
\hline \multicolumn{2}{|c|}{ Nilai Min } & 1245 & 323 & 1851 & 3618 & $32 \%$ & $9 \%$ & $51 \%$ & $11 \%$ \\
\hline
\end{tabular}

Kompetensi perekam medis dan informasi kesehatan yang disebut dengan Standar Profesi Perekam Medis adalah batasan kemampuan minimal yang harus dikuasai oleh PMIK untuk dapat melaksanakan pekerjaan lingkup rekam medis secara profesional yang diatur oleh organisasi profesi (Permenkes RI, 2013). Salah satu kompetensi PMIK adalah mampe menetapkan kode penyakit dan tindakan dalam rekam medis, berdasarkan hasil penelitian dari Nuryati, dkk (2016) dinyatakan bahwa akan menjadi kendala dalam menetapkan kode diagnosis dan tindakan dikarenakan petugas tidak memahami struktur sistem klasifikasi, hal ini terjadi karena petugas tersebut bukan perekam medis. Hasil tersebut senada dengan hasil penelitian dari Sudra \& Pujihastuti (2016) bahwa terdapat pengaruh secara parsial dan signifikan antara pengetahuan petugas PMIK terhadap keakuratan kode diagnosis dengan nilai $\mathrm{p}=0,010$.

Sedangkan menurut Priansa (2016) Kompetensi kerja adalah kemampuan pegawai yang dipetakan dari kemampuan secara pengetahuan, keterampilan umum dan khusus, kematangan berfikir dan menganalisis, pengalaman yang mendukung, keefektifan, keefisienan, dan kesuksesan dalam menjalankan tanggungjawab pekerjaan.

Dalam penelitian ini penilaian terhadap pencapaian kompetensi PMIK selaras dengan penilaian kinerja yang dilakukan kepada pegawai PMIK. Priansa (2016) menyatakan bahwa penilaian kinerja dari pegawai merupakan evaluasi yang dilakukan secara sistematis terhadap jenis pekerjaan yang telah dillakukan oleh pegawai, kegiatan tersebut bertujuan untuk pengembangan kemampuan dan evaluasi pegawai. Sedangkan menurut 
Mathis dan Jackson dalam Priansa (2016) penilaian kinerja (performance appraisal) dilakukan untuk mengevaluasi bagaimana pemenuhan kemampuan bekerja dari pegawai berdasarkan seperangkat standar yang telah ditentukan, selanjutnya hasil tersebut dikomunikasikan kepada pegawai yang bersangkutan. Dalam penelitian ini pegawai yang dimaksud adalah pegawai PMIK yang bekerja di rumah sakit wilayah kota Yogyakarta sedangkan seperangkat standar yang dimaksud adalah Surat Keputusan Dewan Pimpinan Pusat PORMIKI No. 08/PORMIKI/XI/2016 tentang Pemberlakuan Atas Draft Standar Kompetensi Baru Perekam Medis dan Informasi Kesehatan. Kinerja pegawai dapat juga dipengaruhi oleh motivasi. Motivasi mempunyai pengaruh positif dan signifikan terhadap kinerja dari pegawai, baik motivasi yang berasala dari dalam diri (intrinsik) maupun motivasi yang berasal dari lingkungan (ekstrinsik), hal ini sesuai dengan hasil penelitian Rahmah, dkk (2013).

Penilaian kinerja dalam penelitian ini dilakukan dengan metode seft assessment, Menurut Rolheiser \& Ross (2014) seft assessment merupakan salah satu metode yang digunakan untuk melihat kedalam diri sendiri. Melalui seft assessment, pegawai mampu menganalisis kelebihan dan kekurangan dalam bekerja, untuk selanjutnya kekurangan tersebut diperbaiki (improvement goal). Dengan demikian, pegawai lebih bertanggungjawab terhadap proses pelaksanaan dan pencapaian tujuan bekerjanya.

Berdasarkan hasil dalam penelitian pada tabel 7 dijelaskan pencapaian kompetensi PMIK tertinggi di rumah sakit wilayah kota Yogyakarta yaitu pada kompetensi pertama atau profesionalisme yang luhur yaitu sebanyak $81 \%$ atau dapat dikategorikan tingkat pencapaian PMIK dalam kompetensi tersebut adalah baik, sedangkan tingkat pencapaian kompetensi kerja PMIK terendah di rumah sakit wilayah kota Yogyakarta yaitu pada kompetensi ke enam atau manajemen organisasi dan kepemimpinan yaitu sebanyak $72 \%$ atau tingkat pencapaian kompetensi kerja
PMIK pada kompetensi tersebut sedang. Sedangkan secara keseluruhan tingkat pencapaian kompetensi kerja PMIK di rumah sakit wilayah kota Yogyakarta yaitu sebesar $75,11 \%$.

Selain pendapat dari Seniati (2006) tentang masa kerja mempengaruhi komitmen kinerja. Alim,dkk (2007) mengutip pendapat dari Asthon yang menunjukkan bahwa dalam beberapa literatur psikologi disebutkan mengenai kemampuan dalam pengetahuan secara spesifik dan lamanya pengalaman dalam bekerja menjadi faktor penting dalam meningkatkan kompetensi. Dalam Alim, dkk (2007) juga disebutkan bahwa pendapat Ashton didukung oleh Schmidt et al yang memberikan bukti nyata bahwa terdapat hubungan yang signifikan antara pengalaman kerja dengan kinerja dari pegawai. Penelitian ini selaras dengan pendapat peneliti bahwa pencapaian kompetensi PMIK dapat dilihat dari masa kerja PMIK tersebut. Dalam penelitian ini terdapat kenaikan tingkat pencapaian kompetensi kerja setiap masa dinas dari sedang ke baik.

Namun pada masa dinas lebih dari dua puluh tahun tingkat pencapaian kompetensi kerja menurun dari baik menjadi rendah. Berdasarkan hasil analisis peneliti hal ini berhubungan dengan umur, yang telah dijelaskan dalam gambar 30. umur PMIK pada masa dinas tersebut telah lebih dari empat puluh tahun. Meskipun masih masuk dalam usia produktif, pada umur tersebut penyerapan pemahaman individu terkait kompetensi PMIK tetap akan menurun yang akhirnya mempengaruhi tingkat pencapaian kompetensi kerja PMIK tersebut.

Tingkat pencapaian kompetensi kerja PMIK di rumah sakit wilayah kota Yogyakarta juga dapat disebabkan oleh peran PMIK dalam proses kredensial. Frekuensi responden dalam penelitian ini sebanyak $54 \%$.

\section{PENUTUP}

Terdapat gap antara kurikulum pendidikan tinggi diploma III RMIK dengan kompetensi PMIK, yaitu sebesar 18\%. Gap pencapaian kompetensi antara kurikulum pendidikan tinggi diploma III RMIK dengan kompetensi PMIK berdasarkan area 
kompetensi antara 2\% sampai dengan 30\% dan gap tertinggi terdapat pada area kompetensi komunikasi yang efektif yaitu sebesar 30\%. Gap tertinggi pada pencapaian kompetensi antara kurikulum pendidikan tinggi diploma III RMIK dengan kompetensi PMIK berdasarkan masa kerja 11 - 15 tahun yaitu sebesar 73\%. Gap tertinggi pada pencapaian kompetensi antara kurikulum pendidikan tinggi diploma III RMIK dengan kompetensi PMIK berdasarkan jenis rumah sakit yaitu sebesar $24 \%$. Terjadi penurunan gap pencapaian kompetensi antara kurikulum pendidikan tinggi diploma III RMIK berdasarkan kurikulum yang diterima saat PMIK menempuh pendidikan tinggi, dari gap pada kurikulum sebelum tahun 2012 yaitu sebesar $25 \%$ menjadi $11 \%$ pada gap kurikulum setelah tahun 2012.

Sebaiknya perguruan tinggi dan organisasi profesi melakukan pendataan dan kesepakatan terkait kurikulum dan evaluasi kemampuan dari PMIK.

\section{DAFTAR PUSTAKA}

Menkes RI. (2011). Keputusan Kepala Badan Pengembangan dan Pemberdayaan Sumber Daya Manusia Kesehatan Kementrian Kesehatan Nomor HK.02.05/I/III/2/08661/2011 tahun 2011 tentang Kurikulum Inti Pendidikan Tinggi Diploma III Rekam Medis dan Informasi Kesehatan. Jakarta : Indonesia

Menkes RI. (2003). Keputusan Menteri Kesehatan Nomor 725 Tahun 2003 tentang Pedoman Penyelenggaraan Pelatihan di Bidang Kesehatan. Jakarta : Indonesia

Menkes RI. (2013). Peraturan Menteri Kesehatan Nomor 55 Tahun 2013 tentang Penyelenggaraan Pekerjaan Rekam Medis. Jakarta : Indonesia

Nuryati. (2016). Pencapaian Kompetensi Perekam Medis dan Informasi Kesehatan : Studi Kasus di Daerah Istimewa Yogyakarta. Seminar Nasional Teknologi Terapan: Yogyakarta.

Nuryati, Budi, S,C., Rokhman, N. (2016). Kendala Pelaksanaan Program JKN Terkait Penerimaan Pasien, Pengolahan Data Medis, Pelaporan, dan Pendanaan JKN di Puskesmas Gondokusuman II Yogyakarta. Jurnal Manajemen Informasi Kesehatan Indonesia Vol. 4 No.1 Maret
2016: 41-54. Tersedia dalam http://jmiki.aptirmik.or.id/index.php/j miki/article/view/96/79

PORMIKI. (2016). Surat Keputusan DPP PORMIKI Nomor 8 Tahun 2016 tentang Pemberlakuaan Atas Draft Standar Kompetensi Baru Perekam Medis dan Informasi Kesehatan. Jakarta : Indonesia

Presiden RI. (2012). Peraturan Presiden Nomor 8 Tahun 2012 tentang Kerangka Kualifikasi Nasional Indonesia. Jakarta : Indonesia

Presiden RI. (2003). Undang - Undang Nomor 20 Tahun 2003 tentang Sistem Pendidikan Nasional. Jakarta : Indonesia

Presiden RI. (2009). Undang - Undang Nomor 40 Tahun 2009 tentang Rumah Sakit. Jakarta : Indonesia

Presiden RI. (2012). Peraturan Presiden Nomor 8 Tahun 2012 tentang KKNI. Jakarta : Indonesia.

Presiden RI. (2012). Undang - Undang Nomor 12 Tahun 2012 tentang Pendidikan Tinggi. Jakarta : Indonesia

Rahmah, A., Bachri, A.A., Faidah, A.N. (2013). Pengaruh Komitmen Organisasional, Motivasi Intrinsik, Dan Motivasi Ekstrinsik Terhadap Kinerja Dokter (Studi pada Dokter Rumah Sakit Umum Daerah Ulin Banjarmasin). Jurnal Wawasan Manajemen. Tersedia dalam http://eprints.ulm.ac.id/967/1/JWM\%20 VOL\%20\%201\%20NO\%203.pdf.

Satria, R.O dan Kuswara, A. (2013). Pengaruh Motivasi Dan Pelatihan Terhadap Kompetensi Kerja Serta Implikasinya Pada Produktivitas Pegawai Dinas Perhubungan Kota Bandung. Jurnal Ekonomi, Bisnis \& Entrepreneurship. 7 (2) : $74-83$. Tersedia dalam https://media.neliti.com/media/publicat ions/41285-ID-pengaruh-motivasi-danpelatihan-terhadap-kompetensi-kerjaserta-implikasinya-pad.pdf.

Diakses pada tanggal 1 Juni 2017.

Sudra, R.I \& Pujihastuti, A. (2016). Pengaruh Penulisan Diagnosis dan Pengetahuan Petugas Rekam Medis Tentang Terminologi Medis Terhadap Keakuratan Kode Diagnosis. Jurnal Manajemen Informasi Kesehatan Indonesia. Vol. 4. No.1: 82 - 72. Tersedia dalam http://jmiki.aptirmik.or.id/index.php/j miki/article/view/99/82. 